\title{
Clarion 8
}

Beirut, December I4, I860'

More on the Moral Losses of the Homeland

Countrymen,

One of the moral losses that the homeland has suffered is a loss of what we call integrity or self-respect. Many a time we saw some patriot lowering his gaze-especially these days when foreigners mention this topic - not out of cowardice or fear, but out of embarrassment and shame. How often he would apologize for his fellow countrymen's state of affairs, arguing that it is how most people behave in catastrophes. And yet, the denigrator would retort: "This behavior is a natural product of Arab instinct regardless of current circumstances." Perhaps you are of the opinion that such a claim is hard to refute by someone seeking the truth rather than sophistry. But one cannot pass a moral judgment based on anecdotes. Perhaps, once they review our specific circumstances and understand how humiliated we have been generation after generation, those who denigrate us will consider our situation with more integrity and empathy. Had they found themselves in a similarly humiliating situation, they would hardly have marveled at their downfall into a situation as low and demeaning as ours. 
May fellow countrymen take note and in the future behave in a way that would pull them out of their ignoble situation and restore their self-respect. This will earn them respect in the eyes of others and gradually erase the traits they have acquired under the influence of recent events. One of these acquired traits is the inability to say what one believes and believe what one hears. A foreigner who reads this might exclaim: "Strange, what does the patriot mean? Before the current unrest, were his compatriots any more truthful to claim the events made them less so? And who would believe the words of an Arab-whether rich, well placed, or of noble origin?" This quip is as obvious as a fire on a hilltop. So how and with what do we argue against people questioning our entire race, even as we observe a correlation between their words and reality, especially if we take the race as a whole?

Perhaps our fellow countrymen are displeased to see us repeat the same allegations we are trying to refute. Once, when I was speaking to a man who thinks little of the Arab race and who dismisses all Arabs as cheating liars without exception or consideration of conscience, the Arab blood in me started to boil. In response to his sharp comments, I exclaimed heatedly that lying and cheating are natural dispositions in all peoples and races, a truism backed by what the Messenger has said: "All people are liars."

I did not leave it at that but added: "If Arabs lie more frequently in number and in quantity compared to other races, it is because they lie spontaneously, without deliberation or prudence, nor with a motive or gain in mind, as is the case with the rest of the things they do." But the lying of other races may be graver than that of the Arabs in terms of gravity and quality. For other races lie deliberately and prudently for their own benefit. It is as if their lies are as masterly executed as their deeds. 
It is known that two things hold people from lying: religion and public opinion. If only both were present. As for Arab religions, we do not want to touch this delicate matter for fear of offending the feelings of those who uphold it dearly. It will suffice to ask each person to examine their own religion very closely and see whether it gives them an absolute license to lie, or whether it forbids lying completely, or whether it allows it in certain situations but under special conditions and constraints. We are certain that any religion that allows lying cannot be valid. That is because a true religion is from God, who is the truth and its source, as opposed to lying, which is the work of Lucifer, who is the father of lying and liars. Bear in mind that what some call frivolous, symbolic, or fraudulent lying-what Westerners refer to as "white lies"-is as real and sinister as lying can be. It can even be the fount and precursor to serious deceit, for he who is indifferent to venial sins slowly slips into mortal sins.

As for Arab public opinion, no one can claim that it is opposed to this malicious vice of lying. As our popular street saying goes: "Lies are the salt of men, so shame on the gullible." This saying seems to represent public sentiment in this regard and may be used as proof for what we are arguing. However, in the eyes of the truthful-including nonbelievers - the status of the liar is diminished, whosoever that liar is. As is the case in countries where honesty is highly regarded, those characterized by this vile trait do not deserve to be part of respectable society. They are ostracized because they lack self-respect and a sense of honor.

Now, most of you who are reading this pamphlet will admit that the language of Arabs and their culture - their laws, habits, or social structures, their political relations-may contain more things that foster lying or disrespect for truthfulness than those 
among non-Arabs. Obviously, sparse honesty increases the propensity to disbelieve, and the words of liars are doubted, even when they speak the truth. It is related that once a shepherd was herding the sheep of his father near his hometown when he cried jokingly, "Wolf! Wolf!" People hurried to help him but did not find a wolf. He did that twice and thrice and the people kept coming for help. But then an actual wolf came by and when the boy called for help, no one rushed to his aid. The wolf devoured him and drove away his sheep.

Truth telling and credulity were scarce before the current unrest in this country and became even more so after it-so much so that one could be forgiven for thinking that we are living in a world of make believe, not reality. And since truth telling and credulity are two essential pillars of comfort, security, and success in business and social conduct, their absence constitutes a grave evil and a great loss.

Let's hope that our people will change the previous saying into "Truth is the salt of men, and shame on the liars!" and stick to the new rendition in word and deed. Otherwise, this patriot himself will be obliged to cite what the Cretan poet and prophet once said to his compatriots, as recorded in the Epistle to Titus, namely that vice, like disease, is pervasive among all peoples and races, and so each distinguished itself by a particular bad trait for which each became known. ${ }^{2}$

Who has traits that are all agreeable?

He is noble whose faults are enumerable

Another moral loss was that of general comfort all over the country. Whoever roams Syrian cities, villages, mountains, and plains these days - especially those places that were the theater of war and transgressions-will only come across extremely 
depressing scenes, and will only hear whining, complaints, and dissatisfaction with the misery all around. Even more ruin seems to lie ahead in a different garb. It is possible that one of the results of this unrest is the flight of so much money and so many men that the inhabitants left in the country are in such a state of humiliation and want that many of them will turn into impoverished beggars.

True, we see that a house is being built over here, and a plot of land is being ploughed over there, but we fear that every time a private dome is built, a public shrine is torn down. It was said that one day a cat entered a blacksmith's shop, and licked the rasp. It tasted so sweet that the cat kept on licking until he became tongue-less. How miserable and unfortunate Syria is! How few are its means! And how neglectful its people have been! Would Syria not be better off and able to avoid this miserable state if it could get rid of the murderers that constitute the germs of corruption? It is as if this country is doomed with misfortune and backwardness or - as the saying goes - "Under a curse and abetting its own ruin." It is as if whenever Syria takes one step forward it takes several steps backward. Who can fend off fate and destiny?

Another loss was that of trust between one community and another and among members of the same community. Such a loss strips people of their peace of mind and sense of prosperity. It also stands in the way of their progress and success. One abysmal type of this lack of trust-which has very damaging consequences - is the lack of confidence in the rulers and the ruled or between the subjects and their government. It is widely known that the state officials' trust in ordinary people is largely conditional on the people's trust in them and vice versa. Therefore hard work is required from both sides to regain trust and strengthen its foundations. ${ }^{3}$ 
Let us hope that the heinous effects brought about by the recent events will gradually be alleviated through the corrective actions of ruler and ruled. Rulers need to exercise wisdom, govern with aptitude, and reform their conduct toward their subjects, whom they should respect. Subjects, on the other hand, need to know that their best interest lies in the common good, to exercise forbearance and avoid extremism in seeking a pardon or punishment for what is prohibited politically, religiously, morally, and according to custom. Then, the wheel of trust will eventually spin back to its previous level, based on ties, customs, upbringing, and traits as well as on the common degree of civilization shared between both ruler and ruled.

Another moral loss is that of some people's family honor. Perpetrators of such irreparable loss have surpassed the limits of humanity and gone even further than the savages and barbarians who refrain from heinous acts that are disgusting to the ear and revolting to human nature. Yet another loss is that of many rare books and valuable libraries. In the past, books were saved from the damage of mites, dust, and fire by selling them off cheaply and thus dispensing them to the people. This time around, the hand of cruelty has not exempted books. Nor did the hand of cruelty exempt the herds of animals, not even the silkworm, whose hard labor helps weave clothing to provide for the naked and shield orphans and widows. Finally, we have lost the safety of doing business. Many craftsmen and their practical skills are irreplaceably lost. Who can calculate all this damage to the homeland as well as to the government?

And what about spiritual losses and the corruption of the manners and morals of the public? All of these are hard to miss by the perceptive observers among us. There are other losses that we chose not to mention for brevity's sake or due to their infamy. What we have mentioned in this and the previous two 
addresses will persuade those who want to believe that wars generate enormous evil and that civil wars are the most evil thing under the sun.

Does it befit us to stand by and look on at these losses with our hands tied only to find ourselves in a state of despair and hopelessness, unable to compensate the loss? Nay, our way forward is to roll up our sleeves, to make a determined effort to conduct our affairs calmly and quietly, and to acquire what grants us peace and success. We need to alleviate the damage and destruction around and within us, while avoiding its causes through self-reflection. The rest is best left to Heavenly Prudence and Self-Sufficient Providence, and to the efforts, acumen, and wisdom of those in charge.

These are the material and moral losses we set out to show. God willing, we will follow this with an inventory of moral gains in order to grant this topic its proper due. May God preserve you.

From a patriot 